\title{
Limited importance of primary production in the deep chlorophyll layer for macro-zooplankton in an oligotrophic karst lake: A whole-lake ${ }^{15} \mathrm{~N}$ experiment
}

\author{
Wayne A. Wurtsbaugh1,* iD, María Rosa Miracle ${ }^{2, \dagger}$, Antonio Camacho ${ }^{2}$, Javier Armengol ${ }^{2}$ \\ and Eduardo Vicente ${ }^{2}$
}

1 Watershed Sciences Department/Ecology Center, Utah State University, Logan, UT 84322-5210, U.S.A.

2 Cavanilles Institute for Biodiversity and Evolutionary Biology, University of Valencia, E-46980 Paterna, Spain.

* Corresponding author: wayne.wurtsbaugh@usu.edu

Received: 23/04/20 Accepted: 20/07/20

\begin{abstract}
Limited importance of primary production in the deep chlorophyll layer for macro-zooplankton in an oligotrophic karst lake: A whole lake ${ }^{15} \mathrm{~N}$ experiment

Deep-chlorophyll layers (DCL) in oligotrophic lakes contribute significantly to primary productivity, but the importance of this production for the rest of the food web and for other strata is unknown. In Laguna El Tejo, a sheltered 1.7-ha Spanish karst lake, chlorophyll levels were $<2 \mu \mathrm{g} / \mathrm{L}$ in the epilimnion but reached $10 \mu \mathrm{g} / \mathrm{L}$ in the metalimnion and upper hypolimnion where cyanobacterial picoplankton dominated. Particulate nitrogen levels were 2-14 times higher in the metalimnion than in the epilimnion and $42 \%$ of the primary productivity occurred in the deeper strata where the DCL was located. To address the trophic importance of the high biomass and production in the deep chlorophyll layer, we injected ${ }^{15} \mathrm{NH}_{4}^{+}$and rhodamine into a $0.5-\mathrm{m}$ strata $(15-16 \mathrm{~m})$ in the metalimnion of the lake. The ${ }^{15} \mathrm{NH}_{4}{ }^{+}$taken up by the nitrogen-limited phytoplankton allowed us to measure the importance of biologically mediated transport whereas the rhodamine traced physical eddy diffusion. After 28 days $55 \%$ of the $15 \mathrm{~N}$ could be accounted for: $71 \%$ remained in the metalimnetic seston (11-18 m), $10 \%$ was in the hypolimnetic seston $(18-20 \mathrm{~m}), 11 \%$ was found above in the epilimnetic seston, and only $8 \%$ had sedimented into the anoxic layer below $20 \mathrm{~m}$. Only negligible amounts of rhodamine (corrected for degradation) moved beyond the 14-18 m strata in the lake, but bio-diffusivity of $15 \mathrm{~N}$ was 3 times greater than the physically induced diffusivity of rhodamine. A mixing model indicated that the deep chlorophyll layer contributed only 1-2\% of the diet of epilimnetic macrozooplankton but $14-33 \%$ of the diet of the meta-hypolimnetic zooplankton. The data indicate the overall importance for primary production and the sequestration of nutrients in the DCL, but relatively limited importance for the macrozooplankton in the lake.
\end{abstract}

Key words: deep chlorophyll maxima, DCM, diffusivity, tracer

\section{RESUMEN}

Relevancia limitada de la capa profunda de clorofila para la producción del del macrozooplancton en un lago kárstico oligotrófico: un experimento de adición de $15_{\mathrm{N}}$ en todo el lago

En lagos oligotróficos los máximos profundos de clorofila (Deep-chlorophyll layers, DCL) contribuyen significativamente a la producción primaria, pero se desconoce la importancia relativa que tiene esta producción para el conjunto de la red trófica y para otros estratos lacustres. En la laguna del Tejo, una laguna cárstica española de 1,7 ha de superficie, encajada en una dolina que la protege del viento; los valores de clorofila fueron $<2 \mu \mathrm{g} / \mathrm{L}$ en el epilimnion alcanzando valores de $10 \mu$ $\mathrm{g} / \mathrm{L}$ en el metalimnion y en la parte superior del hipolimnion, donde el picoplancton, formado por picocianobacterias, era dominante. Los valores de nitrógeno particulado fueron entre 2 y 14 veces superiores en el metalimnion que en el epilimnion, dándose el $56 \%$ de la producción primaria en los estratos profundos donde se localizaba el DCL. Para investigar la importancia trófica de la elevada biomasa y producción primaria de este máximo profundo de clorofila, inyectamos $15 \mathrm{NH}_{4}{ }^{+} y$ rodamina en un estrato de 0.5-m en el metalimnion (entre $15-16 \mathrm{~m}$ ). El ${ }^{15} \mathrm{NH}_{4}{ }^{+}$tomado por el fitoplancton (que estaba 
limitado por $N$ ), nos permitió medir la relevancia del transporte biológico; mientras que la rodamina nos permitió trazar la difusión pasiva por causas físicas. Tras 28 días, el destino del $55 \%$ del $15 \mathrm{~N}$ fue: el $71 \%$ permaneció en el seston metalimnético (11-18 m), el $10 \%$ fue localizado en el hipolimnético (18-20 m), el $11 \%$ más arriba, en el seston del epilimnion, y un $8 \%$ habia sedimentado en la capa anóxica, por debajo de $20 \mathrm{~m}$. Únicamente cantidades insignificantes de rodamina (corregida por su degradación) se desplazaron más allá de los $14-18 \mathrm{~m}$ en el lago, pero la biodifusividad del $15_{\mathrm{N}}$ fue 3 veces mayor que la difusividad fisica de la rodamina. Un modelo mixto indicó que el máximo profundo de clorofila contribuyó tan sólo al 1-2\% de la dieta del zooplancton epilimnético, sin embargo, contribuyó al 14-33\% de la del zooplancton meta-hipolimético. Los datos indican la importancia general que para la producción primaria y la captación de nutrientes tiene el DCL, pero también su relativamente limitada importancia para el macrozooplancton en este lago en su conjunto.

Palabras clave: máximos profundos de clorofila, zooplancton, difusividad, trazador

\section{INTRODUCTION}

Oligotrophic lakes and oceans usually have zones enriched in phytoplankton, or deep chlorophyll layers (DCL) below the mixed layer (Fee, 1976; Camacho, 2006; Cullen, 2015; Silsbe \& Malkin, 2016; Leach et al., 2018). The peak in chlorophyll is frequently referred to as the deep chlorophyll maximum (DCM). DCLs can account for over $50 \%$ of primary production in oligotrophic systems and contain much of the particulate organic matter (seston) in the water column (Silsbe \& Malkin, 2016; Giling et al., 2017; Scofield et al., 2020). The high production in the DCL is a consequence of physiological adaptions of the phytoplankton taxa living there (Camacho \& Vicente, 1998; Camacho et al., 2001; Camacho, 2006; Cullen, 2015). Much of the research on DCLs has focused on the mechanisms that drive their formation (e.g. Pilati \& Wurtsbaugh, 2003; Cullen, 2015; Scofield et al., 2017; Lofton et al., 2020), transport of nutrients between strata (e.g. Pilati \& Wurtsbaugh, 2003; Letelier et al., 2004), and their importance as a food source for grazing zooplankton which often migrate between the surface and deep layers (Williamson et al., 1996; Winder et al., 2003). The relative influence of top-down vs. bottom-up control on algal composition and dominance in the DCL varies across phytoplankton groups (Lofton et al., 2020). Additionally, the importance of DCLs for zooplankton feeding in lakes has been debated, with some studies showing them to be very important (Matthews \& Mazumder, 2005; Francis et al., 2011; Twiss et al., 2012) whereas others have found a limited role (Wilkinson et al., 2014). Some of this research has focused on diel vertical migration
(DVM) of zooplankton that often inhabit the darker, colder water during the day to avoid fish predation, and move into the mixed layer at night, presumably to feed on higher quality foods (Lampert et al., 2003). The underlying assumptions of these migration studies have, however, been questioned (Wurtsbaugh \& Neverman, 1988; Williamson et al., 1996; Armengol et al., 2012).

To address some of these questions, we injected a stable isotope of nitrogen $\left(15 \mathrm{NH}_{4}{ }^{+}\right)$ along with inert rhodamine into the deep chlorophyll layer of a small doline lake in central Spain. The plankton in the lake, Laguna El Tejo, are nitrogen limited (Camacho et al., 2003a), so the tracer was quickly incorporated into the food web. The ensuing isotopic analyses and routine limnological sampling allowed us to address the following questions: (1) How important is the DCL for production processes? (2) What taxa dominate in the DCL? (3) How important is production in the DCL for grazing zooplankton? (4) How fast is biological movement of the $15 \mathrm{~N}$ in relationship to physical processes that move the rhodamine? (5) What is the half-life of nitrogen in Laguna El Tejo?

\section{MATERIAL AND METHODS}

\section{Study site}

The experiment was conducted in Laguna El Tejo, located at $39.987^{\circ} \mathrm{N}, 1.878^{\circ} \mathrm{W}, 20 \mathrm{~km}$ east of the city of Cuenca, Spain. The circular lake lies at an elevation of $1012 \mathrm{~m}$ in a karst depression with an area of only 1.7 ha (Fig. 1A). Steep walls rise $22-50 \mathrm{~m}$ above the entire lake so that it is protected from winds and the surface watershed is very 
small. At the time of the study, the maximum and mean depths of the lake were 26 and $12 \mathrm{~m}$ with a volume of $158000 \mathrm{~m}^{3}$. No surface inflows enter the lake, and sublacustrine springs and precipitation to the lake surface provide water and nutrients. A capped spring located on the south wall of the depression approximately $30 \mathrm{~m}$ above the lake level was sampled occasionally to provide an idea of the nutrient supply in the groundwater. The lake level fluctuates considerably: a morphometric analysis done in 1987 (personal communication, C. Lentisco) indicated that the lake was 5 $m$ deeper than in 1997 when our experiment was conducted and the lake's depth declined approximately $0.4 \mathrm{~m}$ during the 231 days we monitored it. The limnology of lakes in this region has been studied extensively (Miracle \& Vicente, 1983; Miracle et al., 1992; Armengol \& Miracle, 1999; Miracle et al., 2000; Camacho, 2006).

The carbonate rocks in the watershed provide the lake with a $\mathrm{pH}$ varying between 8.5-9.1 in the surface waters, and alkalinities near $5.5 \mathrm{meq} / \mathrm{L}$. Lake whitings from $\mathrm{CaCO}_{3}$ precipitation sometimes occur during summer as in the adjacent and better-studied Laguna La Cruz (Rodrigo et al., 1993; Miracle et al., 2000). Laguna El Tejo is oligo-mesotrophic, with summer epilimnetic chlorophyll $a$ concentrations varying from $1.5-2 \mu \mathrm{g} / \mathrm{L}$ and Secchi depths from 6-7 m. Dissolved inorganic nitrogen and phosphorus concentra- tions are near levels of detection in most cases $(\mathrm{P}<0.9 \mu \mathrm{g} / \mathrm{L} ; \mathrm{N}<0.3 \mu \mathrm{g} / \mathrm{L})$. Both epilimnetic and metalimnetic phytoplankton change seasonally between nitrogen and phosphorus limitation (Camacho et al., 2003a). Dissolved organic carbon in the epilimnion of the lake usually ranges from 3-4 mg/L. Submerged macrophytes (Myriophyllum spicatum and Chara aspera) are intermittently present around the steep littoral zone but are not abundant. Introduced minnows (Luciobarbus guiraonis and Achondrostoma arcasii) are abundant in the lake. The young of both species and adult $A$. arcasii are omnivorous and feed on zooplankton.

\section{N Tracer Injection and processing}

\section{Field collections}

We injected $15 \mathrm{NH}_{4} \mathrm{Cl}$ and rhodamine WT dye into the lake's metalimnion on 17 September 1997 (Fig.1). Prior to the injection $145 \mathrm{~g}$ of 10 -atom $\% 15 \mathrm{NH}_{4} \mathrm{Cl}$ and $652 \mathrm{~g}$ of a rhodamine WT impregnated wax cake were mixed together. To inject the tracers, we pumped water up from a depth of $15.5 \mathrm{~m}$ with an electric pump and mixed it with the $15 \mathrm{NH}_{4} \mathrm{Cl}$ and rhodamine. The mixture was then immediately injected at $4-5 \mathrm{~L} / \mathrm{min}$ through 9 holes in a vertical steel pipe into a $0.5-\mathrm{m}$ thick strata at a depth of $16 \mathrm{~m}$. The tracers
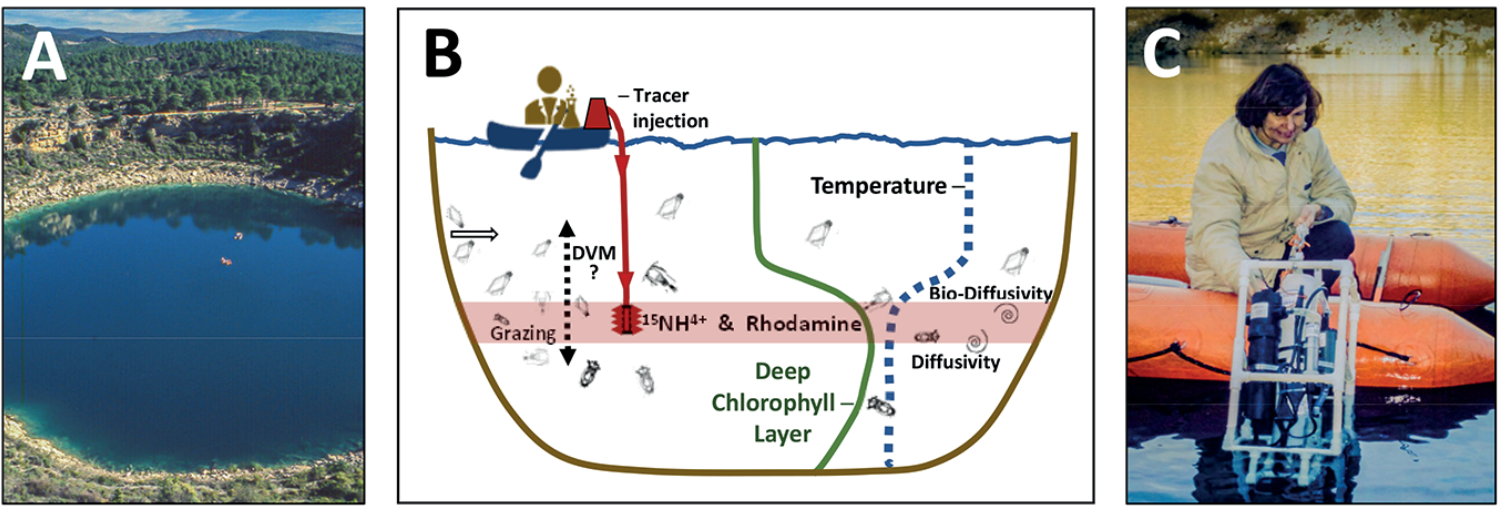

Figure 1. A. Laguna El Tejo with two sampling rafts in upper center. B. Schematic showing tracer injection methods and processes studied. C. Dr. Maria Rosa Miracle sampling with a Seabird salinity-temperature-depth profiler in El Tejo. A. Laguna del Tejo, con las barcas desde las que se hacia el muestreo. B. Esquema que muestra los métodos de inyección del trazador y el $15_{N}$, y los procesos estudiados. C. La Profesora María Rosa Miracle, midiendo la salinidad y temperatura con una sonda multiparamétrica en la Laguna del Tejo. 
were injected for ca. $30 \mathrm{~min}$ at each of 9 stations located roughly equal-distant around the lake over depths $>20 \mathrm{~m}$. Some limited tracer contamination of the epilimnion likely occurred when the hose and pipe were pulled to the surface without first flushing them with epilimnetic water.

The main experiment was run for 28 days. Samples were obtained from the injection date, September $17^{\text {th }}$, to October $15^{\text {th }}$, though measurements of certain variables where taken up to one year later. Seston samples were collected at 7-9 depths between 12:00-19:00 h with a $2.7 \mathrm{~L}$, $50-\mathrm{cm}$ long Ruttner bottle at four stations placed equidistant around the lake over maximum water depths of ca. $23 \mathrm{~m}$. Lake water samples were stored at $4{ }^{\circ} \mathrm{C}$ and processed the next day. We filtered $700-1500 \mathrm{ml}$ of each sample on pre-combusted $\left(550{ }^{\circ} \mathrm{C}, 12 \mathrm{~h}\right) 47-\mathrm{mm}$ WhatmanTM GF/F filters, until clogging occurred. The filters were dried for $24 \mathrm{~h}$ at $45{ }^{\circ} \mathrm{C}$ and frozen. To encapsulate the seston material in tin capsules, a 36-mm diameter punch was used to subsample $81 \%$ of the seston. The encapsulated samples were then frozen at $-20{ }^{\circ} \mathrm{C}$ for up to 3 months before further processing.

Zooplankton were normally sampled between 12:00-20:00 hours with a 25-L Schindler-Patalas plankton trap fitted with a $100-\mu \mathrm{m}$ net. Repetitive casts were made until between 25-200 L of water were collected from each depth. Higher volumes were collected in the epilimnion because zooplankton were sparse there during the day. The $100-\mu \mathrm{m}$ net may have retained a small amount of filamentous phytoplankton in addition to the zooplankton, though this type of phytoplankton is scarce in Laguna El Tejo (Morata et al., 2003; our data). The zooplankton samples were filtered on pre-combusted, 25-mm GF/F filters, placed in Eppendorf capsules, dried $24-48$ hours at $45^{\circ} \mathrm{C}$ and then encapsulated for isotopic processing.

Sedimenting material was collected in four traps placed at each station. The traps were $12-\mathrm{cm}$ diameter, and $50-\mathrm{cm}$ long plastic cylinders. Prior to deployment, these were filled with deionized water containing $5 \mathrm{~g} / \mathrm{L}$ reagent grade $\mathrm{NaCl}$ in order to create a density gradient and harsh conditions to prevent lake water and non-sedimenting plankton, respectively, from entering the trap during deployment. We then injected $120 \mathrm{ml}$ of
$2 \%$ formaldehyde and $1 \%$ of sodium tetraborate into the bottom of each trap to preserve sedimenting material. Formaldehyde has minimal effects on measurements of isotopic enrichment (Bicknell et al., 2011). The traps were then suspended in the anoxic layer with the trap mouth at 21-m for 1-4 weeks. When a trap was brought to the surface, we homogenized the contents, measured the volume, and a 60-100 $\mathrm{ml}$ subsample was filtered on pre-combusted 47-mm GF/F filters. The filters were then dried and processed in the same manner as the seston samples.

\section{${ }^{15} \mathrm{~N}$ analyses and calculations}

Nitrogen mass and isotopic composition were determined with a Europa Scientific ANCA 2020 mass spectrometer. To estimate the flux of $15 \mathrm{~N}$ into different compartments we calculated the increment in the total amount of $15 \mathrm{~N}$ above those at the beginning of the experiment, under the assumption of stable conditions over the 28-day period. We did not collect base-line conditions for the $\delta^{15 \mathrm{~N}}$ of sedimenting material. Consequently, we used the depth-weighted mean $\delta 15 \mathrm{~N}$ of seston in the water column prior to the injection $\left({ }^{+} \delta\right.$ 4.8) as the background level for sedimenting material. If epilimnetic seston, with lower $\delta 15 \mathrm{~N}$ levels $\left({ }^{+} \delta 1.4-1.9\right)$, sedimented more than that in the metalimnion, our calculation would have underestimated the amount of material transported to the sediments.

The proportions of epilimnetic $\left(f_{1}\right)$ and metalimnetic seston $\left(f_{2}\right)$ consumed by zooplankton was estimated with a simple mixing model (Phillips, 2012):

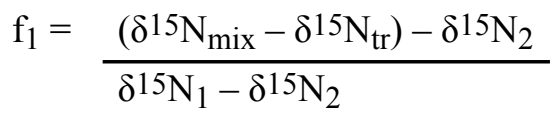

$$
\begin{aligned}
& \mathrm{f}_{2}=1-\mathrm{f}_{1}
\end{aligned}
$$

Where:

$\delta 15 \mathrm{~N}_{\text {mix }}=$ Mean incremental isotopic enrichment above background in zooplankton from a given strata on day 28 of the experiment

$\delta 15 \mathrm{~N}_{\mathrm{tr}}=$ Mean trophic enrichment factor of 
zooplankton above seston prior to tracer addition $(\delta 8.2)$

$\delta 15 \mathrm{~N}_{1}=$ Mean incremental enrichment in seston from epilimnion ( 3 and $8 \mathrm{~m}$ )

$\delta 15 \mathrm{~N}_{2}=$ Mean incremental enrichment in seston from metalimnion (14-18 m)

Rhodamine fluorescence was measured on water samples collected with the Ruttner bottle used for $15 \mathrm{~N}$-seston samples that were frozen and subsequently filtered (GF/F) and analyzed with a Hitachi F4500 fluorescence spectrophotometer set with excitation and emission wavelengths set at 540 and $576 \mathrm{~nm}$, respectively, and with $5 \mathrm{~nm}$ slit widths. Because rhodamine degrades when exposed to light, we conducted an experiment that allowed us to correct for this degradation in the lake. Rhodamine WT was dissolved in deionized water and placed in Pyrex bottles and then either exposed directly to the sun for 120 hours or held in the dark. In the dark bottles there was no significant degradation during the experiment $(p=0.19)$. Light measurements were measured concurrently and the relationship between accumulated light (PAR, in Einsteins $=$ mol Photon $\mathrm{m}^{-2} \mathrm{~s}^{-1}$ ) and rhodamine fluorescence in the bottles was established:

$\%$ of initial $=4.554+-0.00256 \ln ($ Einsteins $)$, $\mathrm{r}^{2}=0.91$

A model of rhodamine degradation in the lake was established using a mean vertical extinction coefficient for PAR of $0.201 / \mathrm{m}$, and assuming 14 $\mathrm{h}$ of full sunlight each day:

$\%$ of initial rhodamine $=\mathrm{e}(4.55-0.00256 * \mathrm{E})$

where $\mathrm{E}=$ cumulative Einsteins over a given number of days

At depths of 10, 14 and $16 \mathrm{~m}$ this resulted in a correction factors of $0.54,0.80$ and 0.82 , respectively, after the 28-day main experiment in the lake. The model, however, did not correct for differential rhodamine degradation with shifting wavelengths at different depths, so it is only approximate.

Eddy diffusivity of the rhodamine $\left(\mathrm{K}_{\mathrm{z}}\right)$ and "biodiffusivity" $\left(\mathrm{K}_{\mathrm{b}}\right)$ of the $15 \mathrm{~N}$ were calculated as follows (Quay et al., 1980):

$$
\mathrm{K}_{(\mathrm{z} \text { or } \mathrm{b})}=\frac{\sigma_{\mathrm{t}}{ }^{2}-\sigma_{\mathrm{o}}^{2}}{2\left(\mathrm{t}-\mathrm{t}_{0}\right)}
$$

Where:

$\mathrm{t}=$ initial $\left(\mathrm{t}_{0}\right)$ and time since injection $\left(\sigma_{\mathrm{t}}\right.$; seconds)

$\sigma_{\mathrm{t}}=$ mean square distance $(\mathrm{m})$

$=1 / 2$ distance between depth at which the

rhodamine or $15 \mathrm{~N}$ was $0.1 \mathrm{x}$ the maximum concentration

$\sigma_{\mathrm{o}}=0.5 \mathrm{~m}$, tracer injection thickness

Initial mean square distances were calculated with data from the mean rhodamine fluorescence profiles recorded $\sim 5$ hours after the injection on a Wetstar ${ }^{\circledR}$ (Wetlabs, Inc.) in situ fluorometer mounted to a Seabird 19 CTD. Fluorescence recorded 7-hours previously was subtracted from the rhodamine signal because phycoerythrin in cyanobacteria fluoresced slightly in the rhodamine spectra. Because rhodamine and $15 \mathrm{~N}$ were injected concurrently, this fluorescence measurement should provide an accurate picture of the relative dispersion of the tracers at the injection depth. Subsequent measurements of the tracers were made from the seston or rhodamine samples collected from the Ruttner bottle. Because the Ruttner bottle was 0.5-m long, and because we sampled only at 1.5-3 m intervals, our estimates of $\mathrm{K}_{\mathrm{Z}}$ and $\mathrm{K}_{\mathrm{b}}$ are not precise. However, the relative magnitudes of the two diffusivity estimates should not have been influenced by the sampling design.

\section{Physical and chemical measurements}

In addition to the Seabird CTD profiles, we collected additional measurements at one station in the lake on each sample date. In situ temperature, conductivity and oxygen profiles were made with WTW meters (LF 191 and WTW Oxi91). Light penetration (photosynthetically active radiation, 400-700 nm) in the lake was measured by a $4 \pi$ scalar irradiance sensor (Li-Cor). Chemical analyses were performed according to standardized methods (Golterman, 1978; APHA, 1992) on three dates (17 Sep, $30 \mathrm{Sep}, 15 \mathrm{Oct}$ ). Ammonia (detection limit $(\mathrm{DL})=2.8 \mu \mathrm{g} \mathrm{N} / \mathrm{L}$ ) was measured 
by the indophenol blue method. Nitrate plus nitrite $(\mathrm{DL}=0.3 \mu \mathrm{g} \mathrm{N} / \mathrm{L}$ ) was measured as nitrite after reduction of nitrate by a cadmium-copper couple in an alkaline solution, and colorimetric determination with sulfanilamide and $\mathrm{N}$-(1-naphtyl) ethylenediamine dihydrochloride. Particulate nitrogen $(\mathrm{PN})$ from samples retained on $\mathrm{GF} / \mathrm{F}$ filters was analyzed with the mass spectrometer as described above. Soluble reactive phosphorus (SRP; DL $=0.9 \mu \mathrm{g} \mathrm{P} / \mathrm{L}$ ) was measured by the phosphomolybdic acid method with ascorbic acid. Total phosphorus $(\mathrm{DL}=0.9 \mu \mathrm{g} \mathrm{P} / \mathrm{L})$ was determined as orthophosphate after persulfuric acid digestion of the sample for $2 \mathrm{~h}$ at $135^{\circ} \mathrm{C}$.

\section{Plankton measurements}

Phytoplankton were identified and counted from each of the sampling depths for samples collected on 17 Sept., 2 Oct., and 15 Oct. Phytoplankton composition was relatively stable on these three dates, and we have consequently presented data from only the midpoint of the experiment (2 Oct.) when the biovolume of each taxon were also estimated. Eukaryotic phytoplankton counts were made using the Utermöhl sedimentation method (Uthermöhl, 1958) in an Olympus inverted microscope at 200-1000 magnification. Species were identified following the taxonomic keys described in Sendra et al. (2019). Biovolume estimates were made by measuring several cells of each phytoplanktonic species, then geometric shapes were used for calculations (Rott, 1981). Picocyanobacterial counts were performed by epifluorescence microscopy on a Zeiss III epifluorescence microscope as described by Camacho et al. (2003c). Chlorophyll $a$ was measured on each sampling date after filtration of the samples
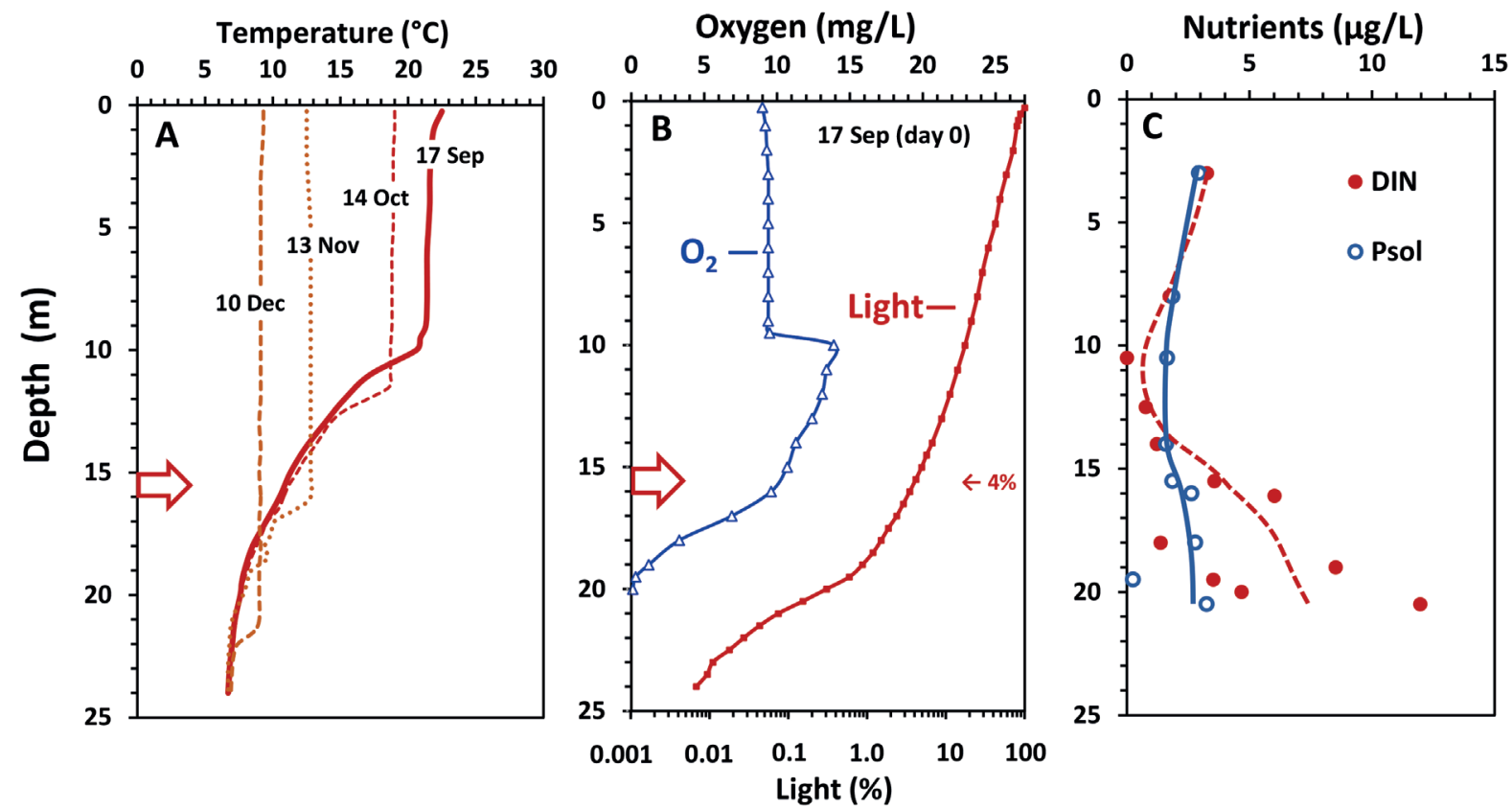

Figure 2. A. Profiles of temperature on five dates during the experiment in Laguna El Tejo. B. Profiles of oxygen concentration and light intensity at the start of the experiment on 17 September. The arrows on the y axes show the depth that $15 \mathrm{~N}$ and rhodamine were injected into the deep chlorophyll layer. C. Mean dissolved inorganic nitrogen (DIN) and soluble reactive phosphorus (SRP) measured on three dates during the 28-day experiment. A. Perfiles verticales de temperatura medidos en cinco fechas diferentes durante el experimento realizado en la Laguna del Tejo. B. Perfiles verticales de la concentración de oxígeno y la radiación luminosa medidos al principio del experimento, el 17 de septiembre. Las flechas muestran la profundidad en la que se inyectó el $15_{N}$ y la rodamina en la profundidad donde estaba localizado el máximo profundo de clorofila. C. Concentraciones promedio de nitrógeno orgánico disuelto (DIN) y fósforo reactivo soluble (SRP) en tres fechas a lo largo de los 28 primeros días del experimento. 


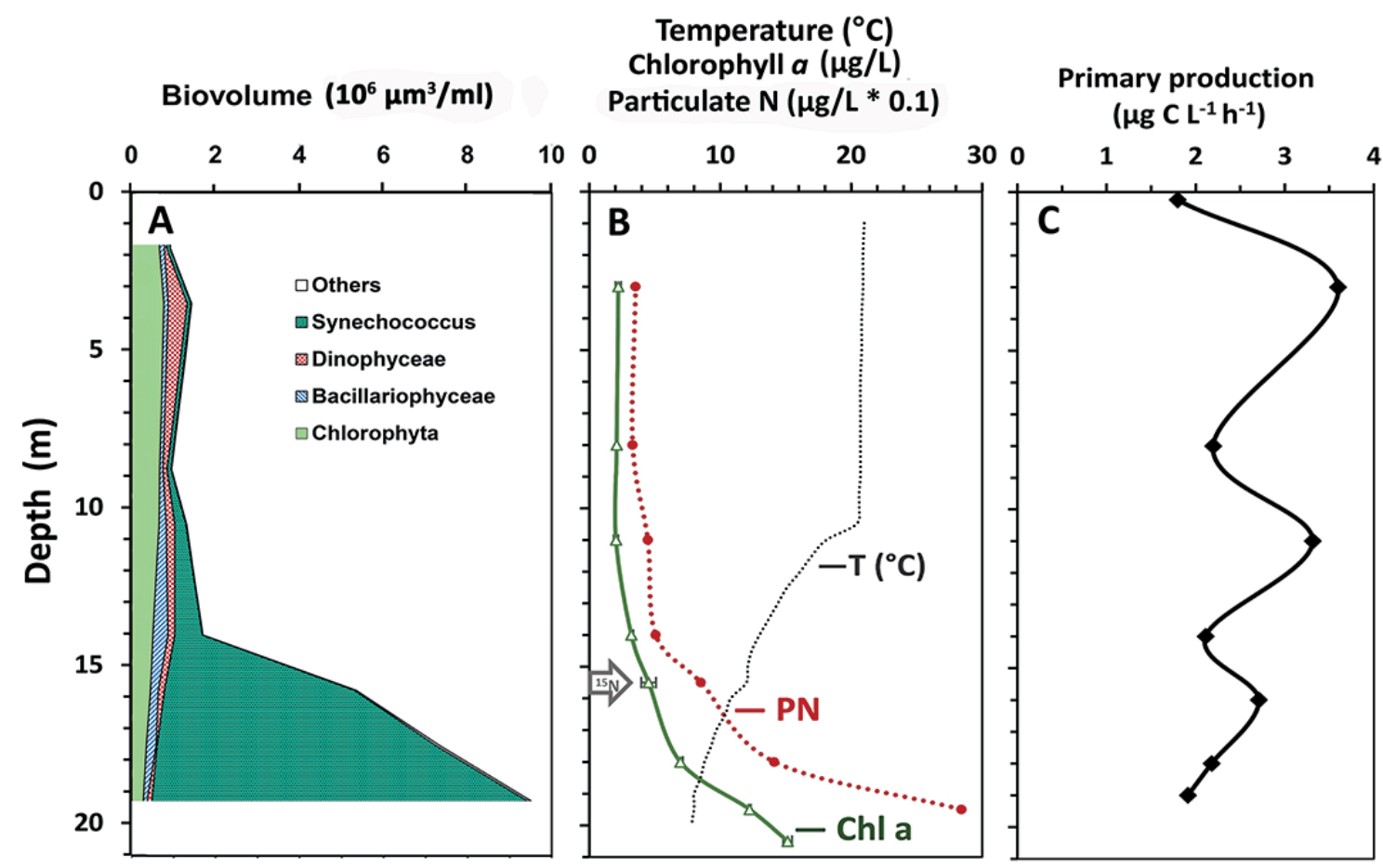

Figure 3. A. Biomass composition of phytoplankton groups in the water column of Laguna El Tejo on Day 15 (2nd-October) of the experiment. B. Chlorophyll $a$, particulate nitrogen concentrations $(\mathrm{PN})$ and temperature in the water column on the Day 13 (30th Sept.). C. Plankton primary production profile on Day 13. A. Composición (en biomasa) de los grupos principales de fitoplancton a lo largo de la columna de agua de la Laguna del Tejo en el día 15 del experimento (2 de octubre). B. Concentraciones de clorofila-a y de nitrógeno particulado (PN) y temperatura en el día 13 del experimento (30 de septiembre). C. Perfil vertical de la producción primaria en el día 13 del experimento.

through a GF/F glass fiber filter, and subsequent extraction with acetone: DMSO, following the procedures described in Picazo et al. (2013). Carbon photosynthetic assimilation was measured in situ on 30 Sept. using the ${ }^{14} \mathrm{C}$ technique (Steeman-Nielsen, 1952) following the procedure described by Camacho \& Vicente (1998). Samples were directly placed in 60-ml tissue culture bottles (Nunclon, Intermed) and kept in the dark during manipulation. Two clear and a dark bottle were used for each depth. $4 \mu \mathrm{Ci}$ of $\mathrm{NaH}^{14} \mathrm{CO}_{3}$ was added to each bottle and they were then incubated at depth for 4 hours. Inorganic carbon estimates were made using measures of alkalinity, $\mathrm{pH}$, temperature, and ionic strength.

Midway through the study (30 Sept. - 1 Oct.) we measured diel vertical migration of the zooplankton at one station. At midday and midnight vertical profiles were made with the
Schindler-Patalas trap and the samples preserved in $4 \%$ formalin for subsequent identification and biomass estimates. Entire samples were counted on an inverted microscope at $100 \mathrm{X}$. For crustacean species, $>100$ individuals were measured to estimate their biomass utilizing length-weight regressions (Lawrence et al., 1987). To characterize the fraction of smaller zooplankton (30-100 $\mu \mathrm{m}$, mainly rotifers) we re-filtered the $1 \mathrm{~L} 100-\mu \mathrm{m}$ filtrate with a $30-\mu \mathrm{m}$ Nitex net. These samples were preserved and counted using an inverted microscope at 100-400 magnification. Estimates of the biomass of rotifers were made following Ruttner-Kolisko (1997).

Four-five minnows were sampled with a seine at the start of the experiment and after 15, 28 and $57 \mathrm{~d}$. These were dried, ground and subsamples were analyzed for $15 \mathrm{~N}$ enrichment as described for zooplankton. 


\section{RESULTS}

\section{Limnological characteristics}

The experiment was conducted during the fall, and consequently the epilimnion cooled and deepened from mid-Sep until December. However, the change was relatively minor during the main experiment, from 17 Sep. to 14 Oct. (Fig. 2A). Oxygen concentration peaked at the top of the metalimnion, where the density gradient minimized upwards diffusion of the photosynthetically-produced oxygen, and declined to $0 \mathrm{mg} / \mathrm{L}$ by $20 \mathrm{~m}$. Secchi disk visibilities were $7.2 \mathrm{~m}$ and $7.4 \mathrm{~m}$, respectively, at the start and end of the 28-day experiment. Light levels declined nearly exponentially through the epilimnion and upper metalimnion but dropped rapidly in the hypolimnion where the deep chlorophyll layer was well developed (Fig. 2B). Light levels were 4 $\%$ of surface intensities at the $15 \mathrm{~N}$ injection point. The depth of $1 \%$ light intensity changed from $18.7 \mathrm{~m}$ at the start of the experiment to $17.9 \mathrm{~m}$ on day 28 . The $1 \%$ light level was near the peak of the Synechococcus layer (see below). Dissolved inorganic nutrients were low in the epilimnion, dropped lower at the top of the metalimnion, and increased below $15 \mathrm{~m}$ in the deep chlorophyll layer (Fig. 2C). On most dates total P in the epilimnion was near the level of detection $(0.9 \mu \mathrm{g} / \mathrm{L})$, increased to $3 \mu \mathrm{g} / \mathrm{L}$ in the upper DCL and reach 16 $\mu \mathrm{g} / \mathrm{L}$ at $20 \mathrm{~m}$. The spring water entering El Tejo that was sampled on three dates had mean concentrations of $3.6 \pm 3.2 \mu \mathrm{g} \mathrm{N} / \mathrm{L} \mathrm{NH}_{4}+, 760 \pm 526 \mu \mathrm{g}$ $\mathrm{N} / \mathrm{L} \mathrm{NO}_{3}{ }^{+} \mathrm{NO}_{2}$ and $1.0 \pm 0.7 \mu \mathrm{g} / \mathrm{L}$ soluble $\mathrm{P}$.

Algal composition in Laguna El Tejo varied markedly with depth (Fig. 3A). In the epilimnion, green algae (Cosmarium laeve, C. abbreviatum, and others) were co-dominants with a large dinoflagellate (Peridinium sp.), a small population of diatoms (Fragilaria ulna, Cyclotella radiosa) and Synechococcus. In the upper part of the deep chlorophyll layer $(11-14 \mathrm{~m})$, green algae $(C$. abbreviatum, $C$. laeve and others) and diatoms (C. radiosa) were abundant, along with dinoflagellates and increasing populations of Synechococcus sp.. A very small population of the cyanobacterium Pseudanabaena sp. was found in the epilimnion and metalimnion on one date. At
15-16 $\mathrm{m}$ in the deep chlorophyll layer, green algae (Chlorella vulgaris; Cosmarium spp.), diatoms $(C . \quad$ radiosa $)$ and dinoflagellates remained abundant, but were overshadowed by increasing densities of Synechococcus which represented $85 \%$ of the phytoplankton biovolume. At the anoxic interface at $19.5 \mathrm{~m}$, the biomass of green algae, diatoms and dinoflagellates decreased and cryptophytes (Cryptomonas erosa, C. phaseolus) and euglenophytes (Euglena agilis) increased moderately. At $19.5 \mathrm{~m}$, however, Synechococcus densities reached 4-5 x 106 cells $/ \mathrm{ml}$, and they represented $95 \%$ of the autotrophic plankton biovolume. At $19.5 \mathrm{~m}$ estimated phytoplankton biovolume was 10-times higher than in the epilimnion.

All three biomass metrics (algal biovolume, seston $\mathrm{N}$ and Chl. a) had similar depth profiles, suggesting that most of the seston was comprised of phytoplankton. However, the seston $\mathrm{N}$ metric also would have included detrital material. The changes in phytoplankton biovolume with depth were paralleled by increases in particulate nitrogen, which increased from $34 \mu \mathrm{g} / \mathrm{L}$ in the epilimnion, to $85 \mu \mathrm{g} / \mathrm{L}$ at the tracer injection depth, to $284 \mu \mathrm{g} / \mathrm{L}$ at $19.5 \mathrm{~m}$ (Fig. 2B). Extracted chlorophyll $a$ concentrations also followed the same pattern as seston $\mathrm{N}$, increasing some in the upper metalimnion and then markedly in the strata where Synechococcus predominated (Fig. 3B). The chlorophyll profile changed little throughout the experiment, with the exception that the low epilimnetic concentrations extended to $12.5 \mathrm{~m}$ by day 28 , coincident with the increased mixing depth (Fig. 2A).

Photosynthesis, on the one day it was measured, had an irregular pattern with one peak in the epilimnion, a second one at the top of the deep chlorophyll layer, and moderate production throughout the Synechococcus layer (Fig. 3C). At $19 \mathrm{~m}$, where the light intensity was only $12 \mu \mathrm{E} \mathrm{m}^{-2}$ $\mathrm{s}^{-1}$, primary production equaled that of phytoplankton at the surface. The production at the top of the deep chlorophyll layer was accompanied by a peak in oxygen concentrations (Fig. 2B).

The deep layers of the lake dominated algal biomass metrics, and to a lesser degree, primary production. Only $21-38 \%$ of the algal biovolume, chlorophyll and particulate nitrogen 


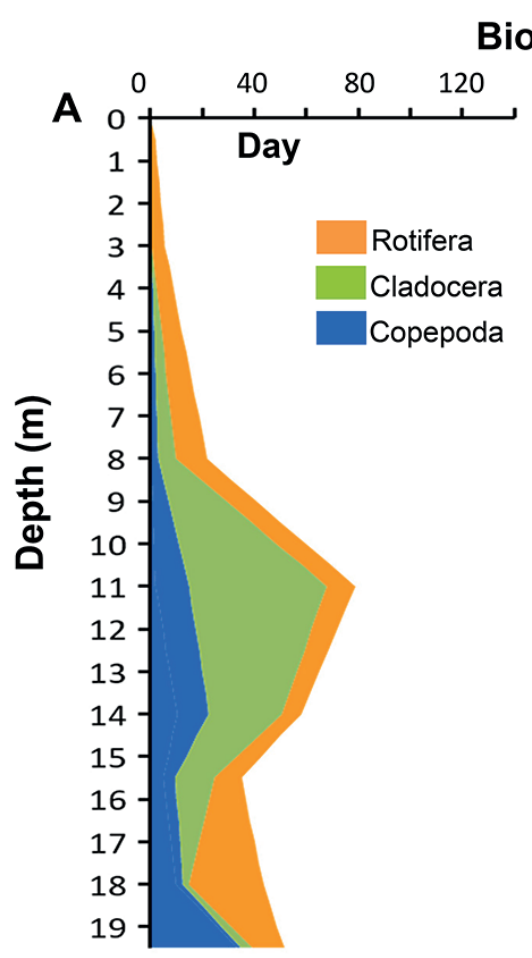

Biomass $(\mu \mathrm{g} / \mathrm{L})$

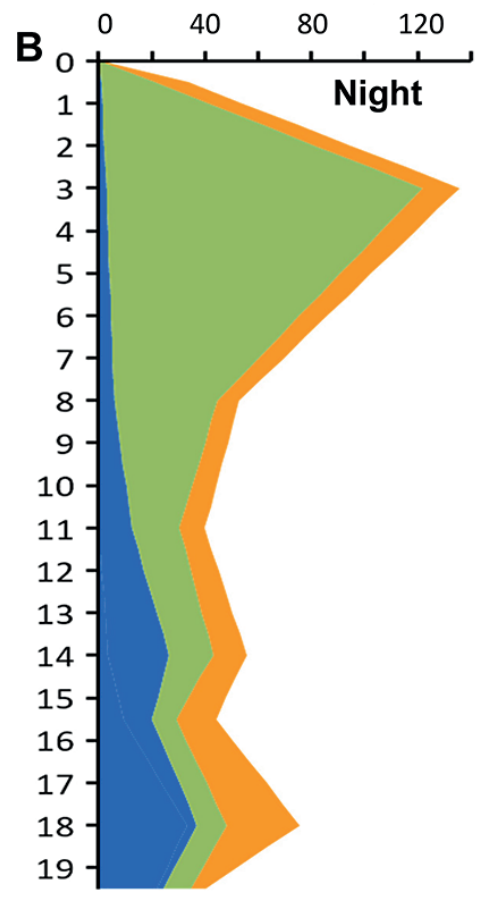

Figure 4. Dry biomass of different zooplankton groups at different depths of Laguna El Tejo (A) during the day and (B) night on 1 Oct. A. Biomasa (peso seco) de los diferentes grupos de zooplancton en el perfil vertical de la Laguna del Tejo (A) durante el día y (B) por la noche, del día 1 de octubre.

biomass occurred in the epilimnion $(0-10.5 \mathrm{~m})$, whereas $58 \%$ of the primary production occurred there (Fig. 3). An additional $10-31 \%$ of biomass metrics occurred in the $10.5-14 \mathrm{~m}$ strata above the Synechococcus-dominated zone, and $19 \%$ of primary production occurred there. The Synechococcus zone (>14 m), accounted for $48-70 \%$ of the biomass metrics, and $23 \%$ of the primary production.

Zooplankton biomass in the lake was dominated by the herbivores Diaphanosoma brachyurum and Tropocylops prasinus and by the predaceous copepod, Cyclops abyssorum (Fig. 4). For both copepods, larval stages (which are mostly herbivores) accounted for a $60 \%$ of their biomass. During the day, the grazers $(D$. brachyurum and $T$. prasinus) occurred primarily in the upper part of the deep chlorophyll layer (11-14 $\mathrm{m}$ ) at temperatures between $13^{\circ}$ and $19{ }^{\circ} \mathrm{C}$. Their densities declined at 15.5 and particularly at 18 and $19.5 \mathrm{~m}$ where Synechococcus increased markedly. At night, the Diaphanosoma increased in the epilimnion, primarily as a result of diel horizontal migration (Armengol et al., 2012). Rotifers represented around $25 \%$ of the biomass in the water column and Anuraeopsis fissa, a species that frequently peaks in the hypolimnion of stratified lakes (Miracle \& Armengol, 1995), were particularly abundant in the Synechococcus zone. Nitrogen concentrations of the zooplankton followed the same profile as the zooplankton biovolume estimates, but concentrations were less than $2 \%$ of that in the seston (data not shown).

\section{$15 \mathrm{~N}$ enrichment of the community}

Prior to the addition of tracers, the natural $15 \mathrm{~N}$ enrichments of phytoplankton and zooplankton community increased with depth (Fig. 5). $\delta 15 \mathrm{~N}$ levels for seston increased from ${ }^{+} 1$ in the epilimnion to +6 in the hypolimnion. Zooplankton $\delta^{15} \mathrm{~N}$ levels increased in a similar manner, 

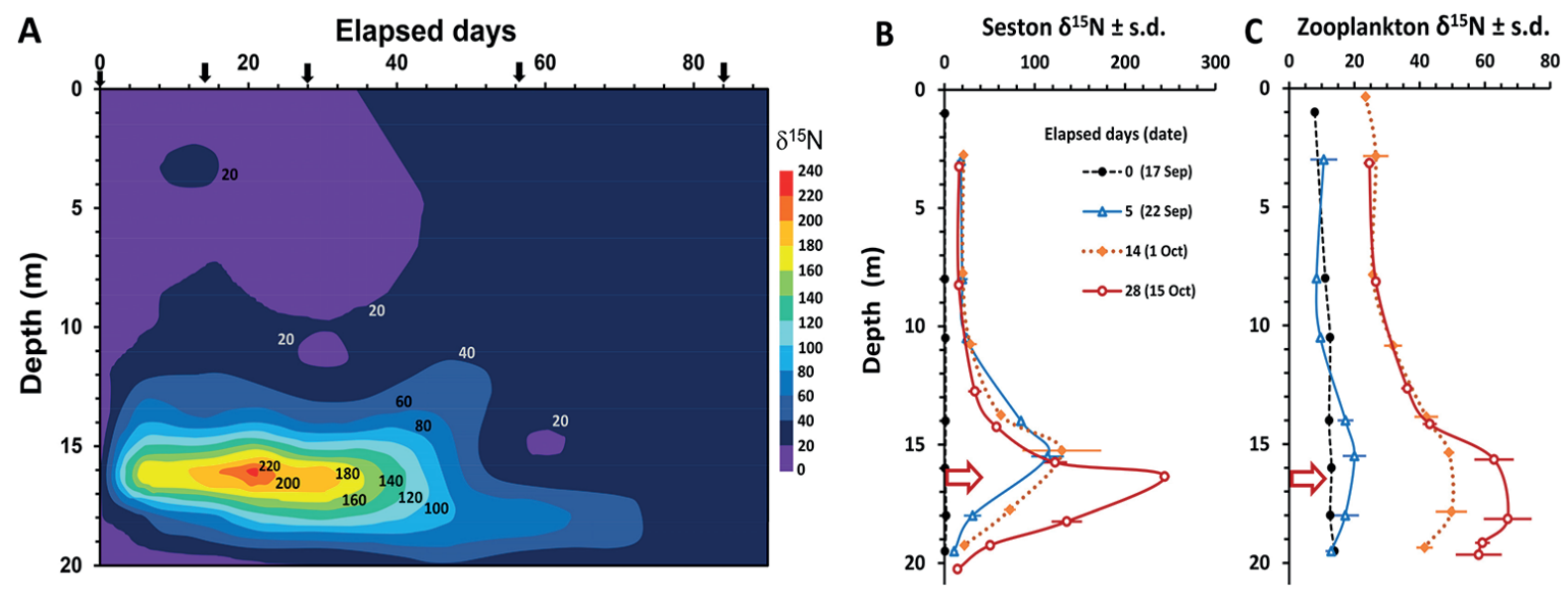

Figure 5. A. Isopleths showing $15 \mathrm{~N}$ enrichment in the seston for the first 85 days of the experiment. Arrows show the dates where isotopic enrichment was measured. B. Depth profiles of $15 \mathrm{~N}$ enrichment of the seston on four dates. C. $15_{\mathrm{N}}$ enrichment of the zooplankton on four dates. A. Isolineas del enriquecimiento en $15 \mathrm{~N}$ del seston en los primeros 85 dias del experimento. Las flechas muestran la fecha y profundidad en la que se inyectó el trazador. B. Perfiles verticales del enriquecimiento en $15_{N}$ del seston en cuatro fechas durante el estudio. C. Enriquecimiento en $15 \mathrm{~N}$ del zooplancton en cuatro fechas durante el estudio.

from +8 near the surface to +14 at $19.5 \mathrm{~m}$. Zooplankton, on average, had a trophic enrichment factor $\left(+\delta^{15 N}\right) 8.2$ units above the seston.

After the addition of $15 \mathrm{NH}_{4}{ }^{+}$, the seston pool became labeled with the tracer, particularly near the depth of the injection (Fig. 5A-B). Within 5 days $\delta^{15 \mathrm{~N}}$ levels at $15.5 \mathrm{~m}$ increased to ${ }^{+} 110$ and continued to increase until day 30 . On day $30 \mathrm{we}$ sampled one additional depth $(16.1 \mathrm{~m})$ and found even higher labeling there. Surprisingly, by day 5 $15 \mathrm{~N}$ labeling also increased to near +20 in the epilimnion, likely the result of contamination when our injection tube with pulled up from $15.5 \mathrm{~m}$ without first flushing it. Epilimnetic seston labeling did not increase subsequently during the main 28-day experiment. By 13 Nov. when winter mixing had begun, seston enrichment was near +30 throughout the mixed layer that extended to $16 \mathrm{~m}$, and by $10 \mathrm{Dec}$. the lake was nearly isothermal (Fig. 2A) and the isotope had mixed throughout the water column, enriching the seston to +33 (Fig. 5A).

Zooplankton also became enriched with $15 \mathrm{~N}$, particularly in the deep chlorophyll layer (Fig. 5C). After 5 days, enrichment was limited to zooplankton in the deep chlorophyll layer, but by days 14 and 30, zooplankton became enriched throughout the water column. In the epilimnion, enrichment averaged +26 , higher than the seston in that layer, but consistent with the trophic enrichment factor noted prior to the tracer addition, indicating that the epilimnetic zooplankton were feeding little in the deep chlorophyll layer. In the deep chlorophyll layer, zooplankton enrichments peaked at +50 (day 14) and +67 (day 30) at $18 \mathrm{~m}$.

The mixing model analysis of zooplankton diets also indicated that zooplankton collected in the epilimnion (3-8 $\mathrm{m}$ ) were consuming almost entirely seston from that layer (Fig. 6; 3-8 m). At the top of the metalimnion (12.5-14 m), the model estimated that $14 \%$ of the diet was from the deep chlorophyll layer, and in the Synechococcus layer (15.5-19 m), $33 \%$ of the zooplankton diets were from that layer, with $64 \%$ estimated to have been from epilimnetic seston.

$15 \mathrm{~N}$ injected into the deep chlorophyll layer and incorporated in the seston and zooplankton moved in the water column 10 times faster than the rhodamine (Fig. 7). Vertical bio-diffusivity for the $15 \mathrm{~N}$ seston was $1.24 * 10^{-6} \mathrm{~m}^{2} / \mathrm{s}$ and the diffusivity of rhodamine was only $0.12 * 10^{-6} \mathrm{~m}^{2} / \mathrm{s}$.

$\delta 15 \mathrm{~N}$ increased slightly in fish from $+10.6 \pm$ 0.2 at the start, to $+12.0 \pm 1.7$ on day 28 ( $p=$ 


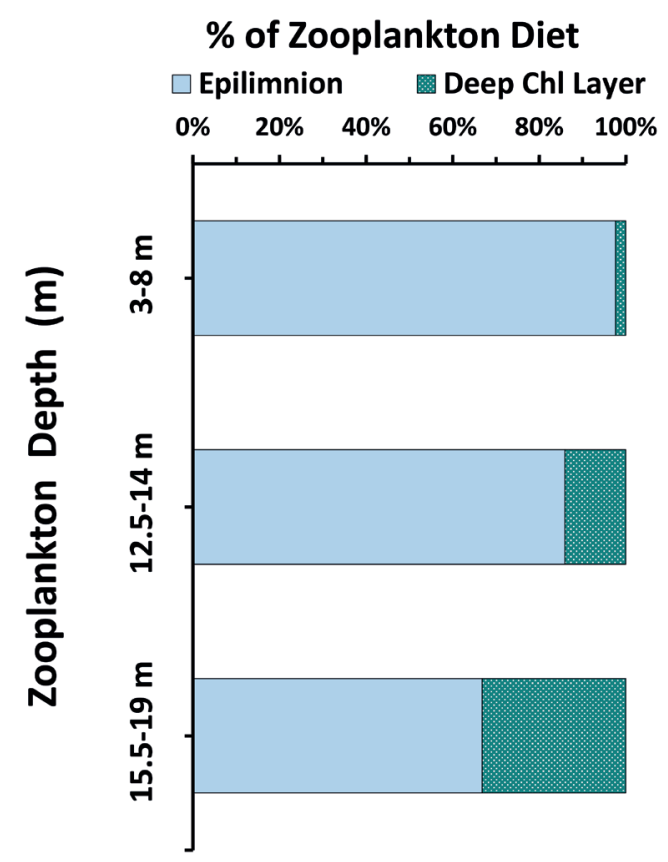

Figure 6. Mixing-model estimates of the diet proportions of macrozooplankton from different depths consumed from the epilimnion, and from the deep chlorophyll layer. Because the model assumes that the zooplankton had reached isotopic equilibrium, the diet proportion from the deep chlorophyll layer may be underestimate. Data are for day 28 of the experiment. Estimaciones, mediante un modelo mixto, de la proporción de la dieta del macrozooplancton de diferentes profundidades consumida en el epilimnion y en el máximo profundo de clorofila. Dado que el modelo asume que el zooplancton ha alcanzado su equilibrio isotópico, es posible que la proporción de la dieta ingerida en el máximo profundo haya sido subestimada. Los datos corresponden al día 28 del experimento.

$0.09)$, but then decreased to $+9.9 \pm 1.3$ in mid-November $(p=0.63)$, indicating that fish benefited little from the deep chlorophyll layer.

An analysis of the $15 \mathrm{~N}$ distribution on day 28 indicated that $55 \%$ of the injected tracer was accounted for. The seston in the metalimnion (11.5-18m) accounted for over $70 \%$ of this, indicating relatively little movement into the epilimnion and hypolimnion (Fig. 8). Zooplankton incorporated only $1 \%$ of the $15 \mathrm{~N}$ that was added and $8 \%$ was found in the sediment traps. Mean sedimentation rates for the first and second two-week periods were 26.7 and $21.8 \mathrm{mg} \mathrm{N} \mathrm{m}^{2} / \mathrm{d}$, but these were not significantly different (2-tailed t-test, $p=0.16)$. Average particulate nitrogen levels in the 20-m water column above the traps was $1400 \mathrm{mg} \mathrm{N} / \mathrm{m}^{2}$, yielding an average daily loss rate of $1.6 \% / \mathrm{d}$. In contrast, the sedimentation loss rate for $15 \mathrm{~N}$ was eight times lower: only $0.2 \% / \mathrm{d}$.

The year-long analysis of $15 \mathrm{~N}$ in the epilimnion of El Tejo showed that the tracer declined exponentially after the lake mixed (Fig. 9). After 335 days post-injection the epilimnetic seston remained $+\delta 5.6$ above background enrichment. The decline was slow, with an estimated tracer half-life of $170 \mathrm{~d}$.

\section{DISCUSSION}

The sampling demonstrated that much of the algal production (42\%) and biovolume (78\%) in this karst lake occurred in the metalimnion and hypolimnion. This has routinely been found in oligotrophic lakes and oceans (Giling et al., 2017) and even in many mesotrophic systems

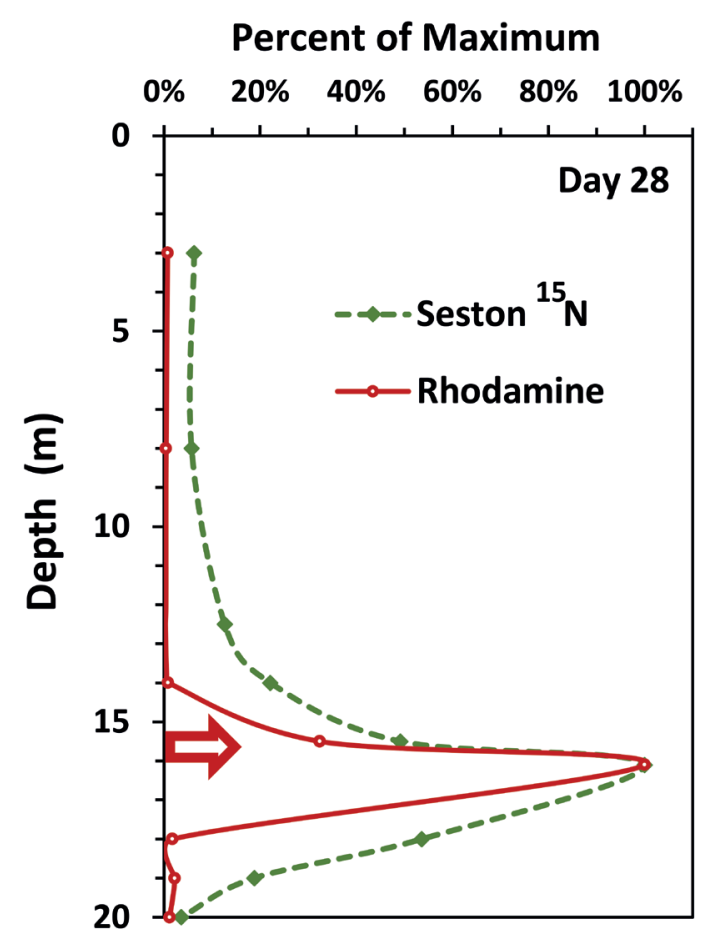

Figure 7. Distribution of rhodamine and $15 \mathrm{~N}$-labeled seston on day 28 of the experiment. The arrow shows the injection depth of the tracers. Distribución de la rodamina y del seston marcado con $15_{N}$ en el día 28 del experimento. La flecha muestra la profundidad de inyección de los trazadores. 


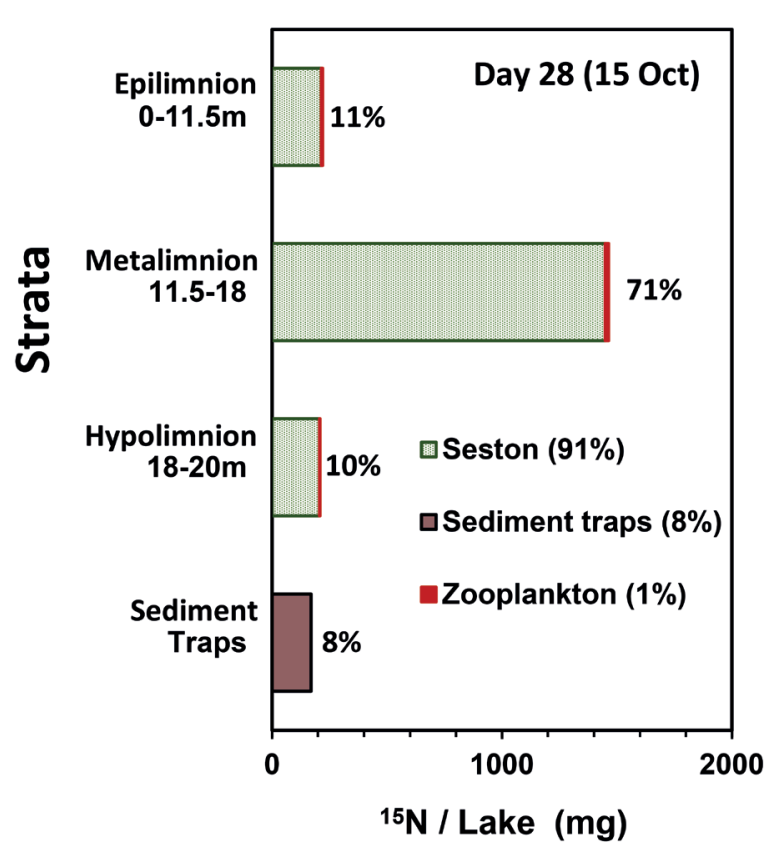

Figure 8. Estimated distribution of the $15 \mathrm{~N}$ recovered at the end of the experiment (day 28). Distribución estimada del $15_{N}$ recuperado al final del experimento (día 28).

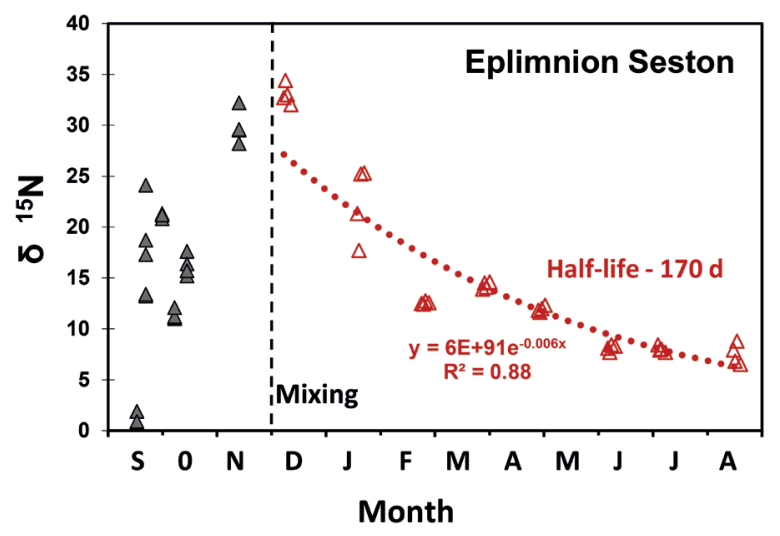

Figure 9. Enrichments of $15 \mathrm{~N}$ in the seston of Laguna E1 Tejo over one year. The solid grey triangles show isotopic enrichment of seston prior to lake mixing. The red open triangles show the decline in enrichments after the lake had mixed nearly to the bottom. Enriquecimiento en $15_{N}$ del seston en la Laguna del Tejo un año después de la inyección. Los triángulos grises muestran el enriquecimiento del seston antes de la mezcla del lago. Los triángulos rojos vacios muestran la caída del enriquecimiento tras la mezcla vertical del lago.
(Williamson et al., 1996). In Lake El Tejo, phytoplankton biomass and chlorophyll levels began to increase in the top of the metalimnion, but the large increase was deep in the water column where a cyanobacterial Synechococcus population developed at a light intensity near $4 \%$ of surface radiation. Although DCLs frequently development near the top of the metalimnion, Leach et al. (2018) found that $33 \%$ of lakes they analyzed with DCM had chlorophyll peaks below the metalimnion. They also found that the median light level for development of the DCM was $4.8 \%$, similar to that found in El Tejo, whereas DCL are common at up to $1 \%$ PAR depths (Camacho, 2006; Scofield et al., 2020).

Deep chlorophyll layers are typically composed of motile algal species and/or neutrally buoyant cyanobacteria with gas vacuoles or ballast substances (Richardson \& Cullen, 1995; Camacho et al., 2000; Leach et al., 2018). The upper part of the DCL in El Tejo was due primarily to a diatom (Cyclotella radiosa), but the large increase in chlorophyll and algal biomass was due to Synechococcus, which has a diameter near $2 \mu \mathrm{m}$ and a low cellular density, thus having negligible sinking rates (Camacho et al., 2003b). The large peak in Synechococcus is similar to that of the nearby Lake La Cruz (Camacho et al., 2003c) where active growth occurs in the deeper part of the metalimnion, and cell densities reach nearly $10^{7}$ cells $/ \mathrm{ml}$. Light-harvesting and growth of these picocyanobacterial is possible in the deep layers because they contain phycoerythrin (Camacho et al., 1996; Camacho et al., 2001; Camacho et al., 2003b). Consequently, they can thrive at depths where nutrient availability is higher than in the surface layers (Camacho, 2006). Moreover, our primary production determinations showed a peak of carbon assimilation coinciding with the deeper DCL formed almost exclusively by Synechococcus, which evidenced in situ photosynthetic activity even near the oxic-anoxic interface. However, its activity was much lower per biomass unit than the upper (subsurface and metalimnion) primary production peaks, which yield higher specific productivity (production/biomass). Earlier experiments demonstrated that even though they have phycoerythrin, the Synechococcus are nevertheless light 
limited, but they take advantage of the higher nutrient availability in these deeper layers to support in situ growth (Camacho et al., 2003b). Negligible sinking rates and low grazing pressure in the cold hypolimnion minimize population losses of Synechococcus in the DCL, allowing high biomass accumulation, despite low growth rates (Camacho et al., 2003a, 2003b).

The seston in El Tejo became heavily labeled with $15 \mathrm{~N}$ within five days of the addition, primarily in the DCL at $15.5 \mathrm{~m}$. On day 28 of the experiment we sampled $15 \mathrm{~N}$ slightly deeper $(16.1 \mathrm{~m})$ because rhodamine profiles measured with the WetStar fluorometer mounted on the Seabird CTD indicated the peak was there, and we found that isotopic labeling was nearly double that of the seston at $15.5 \mathrm{~m}$. The higher enrichment at $16.1 \mathrm{~m}$ was likely due to either a slight measurement error with our injection line, or to a higher density of the injected tracers that could have carried them below their injection point. The seston in the epilimnion was also enriched to $\delta^{+} 18$ within five days but showed no additional enrichment during the main 28-day experiment. Wilkinson et al. (2014) injected $13 \mathrm{C}$ tracer into the metalimnion of a similar-sized lake and found no enrichment of seston in the epilimnion until after 20 days. Consequently, we believe the epilimnetic enrichment in El Tejo was primarily due to some spillage from our raft, or from accidental addition when the injection tube was raised from depth without first flushing it. Rhodamine was not measured on the first sampling date following the injection, but on day 16 of the experiment average epilimnetic rhodamine was $2.6 \%$ of the concentration at $15.5 \mathrm{~m}$, indicating that some tracer contamination of the epilimnion occurred during the injection.

After 28 days we were only able to account for $55 \%$ of the $15 \mathrm{~N}$ tracer. Other pools that we did not measure that could account for this missing tracer are: (1) $15 \mathrm{~N}$ uptake by periphyton or benthic bacteria, which can be significant in oligotrophic lakes (Brothers et al., 2016; Vadeboncoeur \& Power, 2017); (2) denitrification, which could have been appreciable since the ${ }_{15} \mathrm{NH}_{4}{ }^{+}$injected could have easily been nitrified and then denitrified at the interface of the oxic-anoxic zone at 19-20 m (e.g. Brezonik,
2013; Castellano-Hinojosa et al., 2017); (3) $15 \mathrm{NH}_{4}+$ in the injection strata which was not taken up by the plankton and tracer transformed into dissolved inorganic nitrogen, neither of which were analyzed for; (4) tracer leaving the lake via groundwater, and; (5) errors in our measurements of the other pools. Because we didn't have a lake-wide estimate of fish abundance or biomass we could not calculate the amount of $15 \mathrm{~N}$ moving into this pool, but the insignificant $15 \mathrm{~N}$ enrichment in their tissue, and the normally small contribution of fish to the biomass of the biota (Wurtsbaugh, 2007), suggests they were not an important pool for the tracer.

Only $8 \%$ of the recovered tracer had fallen into the sediment traps. This low amount was not surprising given that: (1) much of the tracer was likely incorporated into Synechococcus, with very low sedimentation rates (Camacho et al., 2003b; Camacho, 2006) and; (2) macrozooplankton grazing in the DCL was likely very low, with consequent low export of fecal material that can account for significant losses of particulate matter from the water column of lakes and oceans (Pilati \& Wurtsbaugh, 2003; Turner, 2015; Maszczyk \& Wurtsbaugh, 2017). Additionally, grazing on the abundant Synechococcus was likely done by the abundant rotifer, Anuraeopsis fissa, that graze bacteria and picoplankton efficiently (Ooms-Wilms, 1997; Twiss et al., 2012). This, however, would not cause vertical movements of the $15 \mathrm{~N}$, since rotifers have limited vertical migrations (Armengol \& Miracle, 2000) and they do not produce dense (settling) excreta such as the fecal pellets of copepods. The sedimentation rate of the $15 \mathrm{~N}$ was eight times lower than the sedimentation rate of unlabeled $\mathrm{N}$, suggesting that much of the settling material originated above the heavily labeled Synechococcus layer.

The comparison of the final rhodamine and $15 \mathrm{~N}$ profiles in the DCL indicated that biotic processes were 10X more important for tracer movement than the physical process of vertical eddy diffusion. One obvious reason for the faster movement of $15 \mathrm{~N}$ was sedimentation of the phytoplankton and excreta of zooplankton that fed in this layer. Although $15 \mathrm{~N}$ sedimentation rates were low, they likely contributed to the downward spread of the tracer. The greater 
upward movement of the tracer could have been due to mobile flagellates, or to $15 \mathrm{~N}$ in the excreta of zooplankton that had some vertical movement in the water column (Fig. 4; Armengol et al., 2012). The greater dispersion of the $15 \mathrm{~N}$ must be viewed in the context of the low diffusivity of the rhodamine tracer, $0.12 * 10^{-6} \mathrm{~m} 2 / \mathrm{s}$, which is near that for molecular diffusion (Kalff, 2002). This low diffusivity is consistent with the very small fetch of El Tejo $(140 \mathrm{~m})$ and the surrounding $20-50 \mathrm{~m}$ cliffs that protect the lake from winds. Based on the surface area of El Tejo, the equation of Maiss et al. (1994) predicts a rhodamine diffusivity of $0.435 \times 10^{-6} \mathrm{~m}^{2} / \mathrm{s}$, somewhat higher than what we observed, but consistent with the wind-protected lake surface. The higher diffusivity for ${ }^{15} \mathrm{~N}$ via biotic processes (biodiffusivity) is important because researchers often address the upward vertical movement of nutrients as a strict consequence of the physical mixing processes, and thus they are likely underestimating the true movement of nutrients. Although biodiffusivity has been studied extensively to address solute transport from the sediments (Matisoff, 1996; Kristensen et al., 2012), its importance in the water column has focused primarily on how zooplankton influence physical mixing (Simoncelli et al., 2017; but see Pilati and Wurtsbaugh (2012); Houghton et al., 2018).

After fall mixing dispersed $15 \mathrm{~N}$ throughout the water column, we continued to sample the epilimnetic seston until the following August, allowing us to estimate a half-life for this tracer of $170 \mathrm{~d}$. Given that there are no surface inflows to El Tejo, and that the lake lost depth during our study, we expect that groundwater exchange with the lake was low during the study thus providing minimal flushing. However, we do not have a water residence time to compare with the $15 \mathrm{~N}$ tracer, because we could not use the long-term loss rate of rhodamine due to unknown spectrally-controlled photo-bleaching. Nevertheless, the data demonstrate that denitrification and sedimentation loss of nitrogen was low in this lake.

Our data indicates that the production in the DCL was only moderately important as a food source for crustacean zooplankton, despite the amount of primary production and particularly algal biomass in this layer. After 28 days, only $1 \%$ of the recovered $15 \mathrm{~N}$ was found in the zooplankton. This was somewhat expected, given that only $1.8 \%$ of $\mathrm{N}$ in the plankton was in the crustacean zooplankton. The mixing model also indicated that the DCL was relatively unimportant as a food resource for the zooplankton: only $2 \%$ of the food consumed by epilimnetic zooplankton and $14-33 \%$ by macrozooplankton captured in the DCL was from the deep layer. Many crustacean zooplankton can feed on Synechococcus (Lampert et al., 1986), so the low values were unexpected. We did not, however, measure isotopic enrichment of rotifers, as nearly all of them would have passed through the $100-\mu \mathrm{m}$ mesh we used to separate seston and zooplankton. Rotifers can feed heavily on picoplankton such as the Synechococcus in the DCL of El Tejo (Twiss et al., 2012), so it is likely we underestimated the transfer to the zooplankton. Additionally, the zooplankton sampled on day 28 may not have come into full equilibrium with $15 \mathrm{~N}$ tracer in the seston and this also could have caused us to underestimate the importance of the DCL. However, in a ${ }^{13} \mathrm{C}$ metalimnetic enrichment experiment similar to ours (Wilkinson et al., 2014) zooplankton isotopic labeling was complete within 30 days, suggesting that the plankton in El Tejo may have been close to equilibrium.

Based on their ${ }^{13} \mathrm{C}$ experiment Wilkinson et al. (2014) inferred that the DCL contributed only minimally to the crustacean zooplankton diet, and Sanful et al. (2017) studying natural populations, reached a similar conclusion. However, Francis et al. (2011), using natural-abundance isotopic analyses, concluded that the DCL was a very important food source in oligotrophic lakes. Others have found conflicting evidence of the food value of seston in the DCL (Williamson et al., 1996; Cole et al., 2002). Cold temperatures at the depth of the DCL in El Tejo $\left(8-13{ }^{\circ} \mathrm{C}\right)$ and other lakes should also reduce zooplankton grazing in this stratum (Dawidowicz \& Loose, 1992; Lampert et al., 2003). Much of the literature on the importance of the DCL for zooplankton has focused on diel vertical migration (DVM), and the consumption of deep-chlorophyll phytoplankton during the day when zooplankton migrate into this layer. However, in El Tejo there was minimal DVM of the zooplankton: instead, the increase of 
plankton in the epilimnion at night was due to migration from the epilimnetic sediments or from macrophytes in the littoral zone (Armengol et al., 2012). The importance of the DCL for zooplankton is thus likely dependent on the degree of DVM, which can vary seasonally as the relative amounts and qualities of the seston in the epilimnion and metalimnion change (Brindza, 2002; Matthews \& Mazumder, 2005). Additional work will be necessary to determine the importance of these temporal shifts, and the significance of the DCL for the upper trophic levels in a variety of lakes.

\section{ACKNOWLEDGEMENTS}

We are indebted to Maria Dolores Sendra, who assisted with the phytoplankton determinations, and to Daniel Sanchis, who helped with the field work. Funding was provided by a Fulbright Senior Research Scholarship to WW and NSF grant DEB 9726996, as well as by project CICYT CLI96-1103-CO2-01 granted to MRM by the Spanish Ministry of Education and Science.

\section{REFERENCES}

ARMENGOL, X. \& M. R. MIRACLE. 1999. Zooplankton communities in doline lakes and pools, in relation to some bathymetric parameters and physical and chemical variables. Journal of Plankton Research, 21: 2245-2261. DOI: $10.1093 /$ plankt/21.12.2245

ARMENGOL, X. \& M. R. MIRACLE. 2000. Diel vertical movements of zooplankton in lake La Cruz (Cuenca, Spain). Journal of Plankton Research, 22: 1683-1703. DOI: 10.1093/plankt/22.9.1683

ARMENGOL, X., W. A. WURTSBAUGH, A. CAMACHO \& M. R. MIRACLE. 2012. Pseudo-diel vertical migration in zooplankton: a whole-lake N-15 tracer experiment. Journal of Plankton Research, 34: 976-986. DOI: $10.1093 /$ plankt/fbs058

BICKNELL, A. W., M. CAMPBELL, M. E. KNIGHT, D. T. BILTON, J. NEWTON \& S. C. VOTIER. 2011. Effects of formalin preservation on stable carbon and nitrogen isotope signatures in Calanoid copepods: implications for the use of Continuous Plankton Recorder Survey samples in stable isotope analyses. Rapid Commun Mass Spectrom, 25: 1794-1800. DOI: $10.1002 / \mathrm{rcm} .5049$

BREZONIK, P. L. 2013. Denitrification in natural waters. In: JENKINS, S. H. (ed.) Proceedings of the Conference on Nitrogen As a Water Pollutant. Great Britain: Pergamon.

BRINDZA, N. R. 2002. Analysis of zooplankton grazing rates and the effect of grazing on phytoplankton populations. Master's Thesis, Utah State University.

BROTHERS, S., Y. VADEBONCOEUR \& P. SIBLEY. 2016. Benthic algae compensate for phytoplankton losses in large aquatic ecosystems. Global Change Biology, 22: 3865-3873. DOI: $10.1111 / \mathrm{gcb} .13306$

CAMACHO, A. 2006. On the occurrence and ecological features of deep chlorophyll maxima (DCM) in Spanish stratified lakes. Limnetica, 25: 453-478. DOI: 10.23818/limn.25.32

CAMACHO, A., F. GARCIA-PICHEL, E. VICENTE \& R. W. CASTENHOLZ. 1996. Adaptation to sulfide and to the underwater light field in three cyanobacterial isolates from Lake Arcas (Spain). FEMS Microbiology Ecology, 21: 293-301. DOI: 10.1111/j. 1574-6941.1996.tb00126.x

CAMACHO, A. \& E. VICENTE. 1998. Carbon photoassimilation by sharply stratified phototrophic communities at the chemocline of Lake Arcas (Spain). FEMS Microbiology Ecology, 25: 11-22. DOI: $10.1111 / \mathrm{j}$. 1574-6941.1998.tb00456.x

CAMACHO, A., E. VICENTE \& M. R. MIRACLE. 2000. Ecology of a deep-living Oscillatoria (= Planktothrix) population in the sulphide-rich waters of a Spanish karstic lake. Fundamental and Applied Limnology, 148: 333-355. DOI: 10.1127/archiv-hydrobiol/ 148/2000/333

CAMACHO, A., J. EREZ, A. CHICOTE, M. FLORÍN, M. M. SQUIRES, C. LEHMANN \& R. BACKOFEN. 2001. Microbial microstratification, inorganic carbon photoassimilation and dark carbon fixation at the chemocline of the meromictic Lake Cadagno (Switzerland) and its relevance to the food web. Aquatic Sciences, 63: 91-106. 
DOI: $10.1007 /$ PL00001346

CAMACHO, A., W. A. WURTSBAUGH, M. R. MIRACLE, X. ARMENGOL \& E. VICENTE. 2003a. Nitrogen limitation of phytoplankton in a Spanish karst lake with a deep chlorophyll maximum: a nutrient enrichment bioassay approach. Journal of Plankton Research, 25: 397-404. DOI: 10.1093/plankt/ 25.4.397

CAMACHO, A., M. R. MIRACLE \& E. VICENTE. 2003b. Which factors determine the abundance and distribution of picocyanobacteria in inland waters? A comparison among different types of lakes and ponds. Archiv für Hydrobiologie, 157: 321-338. DOI: 10.1127/0003-9136/2003/0157-0321

CAMACHO, A., A. PICAZO, M. R. MIRACLE \& E. VICENTE. 2003c. Spatial distribution and temporal dynamics of picocyanobacteria in a meromictic karstic lake. Archiv für Hydrobiologie, Supplement, 148: 171-184. DOI: 10.1127/1864-1318/2003/0109-0171

CASTELLANO-HINOJOSA, A., D. CORREA-GALEOTE, P. CARRILLO, E. J. BEDMAR \& J. M. MEDINA-SÁNCHEZ. 2017. Denitrification and biodiversity of denitrifiers in a high-mountain Mediterranean Lake. Frontiers in Microbiology, 8: DOI: 10.3389/fmicb.2017.01911

COLE, P. C., C. LUECKE, W. A. WURTSBAUGH \& G. BURKART. 2002. Growth and survival of Daphnia in epilimnetic and metalimnetic water from oligotrophic lakes: the effects of food and temperature. Freshwater Biology, 47: 2113-2122. DOI: 10.1046/j. 1365-2427.2002.00955.x

CULLEN, J. J. 2015. Subsurface chlorophyll maximum layers: Enduring enigma or mystery solved? Annual Review of Marine Science, 7: 207-239. DOI: 10.1146/annurevmarine-010213-135111

DAWIDOWICZ, P. \& C. J. LOOSE. 1992. Metabolic costs during predator-induced diel vertical migration of Daphnia. Limnology and Oceanography, 37: 1589-1595. DOI: 10. 4319/10.1992.37.8.1589

FEE, E. J. 1976. The vertical and seasonal distribution of chlorophyll in lakes of the Experimental Lakes Area, northwestern Ontario:
Implications for primary production estimates. Limnology and Oceanography, 21: 767-783. DOI: 10.4319/1o.1976.21.6.0767

FRANCIS, T. B., D. E. SCHINDLER, G. W. HOLTGRIEVE, E. R. LARSON, M. D. SCHEUERELL, B. X. SEMMENS \& E. WARD. 2011. Habitat structure determines resource use by zooplankton in temperate lakes. Ecology Letters, 14: 364-372. DOI: 10.1111/j.1461-0248.2011.01597.x

GILING, D. P., P. A. STAEHR, H. P. GROSSART, M. R. ANDERSEN, B. BOEHRER, C. ESCOT, F. EVRENDILEK, L. GÓMEZ-GENER, M. HONTI, I. D. JONES, N. KARAKAYA, A. LAAS, E. MORENO-OSTOS, K. RINKE, U. SCHARFENBERGER, S. R. SCHMIDT, M. WEBER, R. I. WOOLWAY, J. A. ZWART \& B. OBRADOR. 2017. Delving deeper: Metabolic processes in the metalimnion of stratified lakes. Limnology and Oceanography, 62: 1288-1306. DOI: 10.1002/lno.10504

HOUGHTON, I. A., J. R. KOSEFF, S. G. MONISMITH \& J. O. DABIRI. 2018. Vertically migrating swimmers generate aggregation-scale eddies in a stratified column. Nature, 556(7702): 497-500. DOI: 10.1038/ s41586-018-0044-z

KALFF, J. 2002. Limnology. Prentice Hall.Englewood Cliffs.

KRISTENSEN, E., G. PENHA-LOPES, M. DELEFOSSE, T. VALDEMARSEN, C. O. QUINTANA \& G. T. BANTA. 2012. What is bioturbation? The need for a precise definition for fauna in aquatic sciences. Marine Ecology Progress Series, 446: 285-302. DOI: 10.3354/ meps09506

LAMPERT, W., W. FLECKNER, H. RAI. \& B. E. TAYLOR. 1986. Phytoplankton control by grazing zooplankton: A study on the spring clear-water phase. Limnology and Oceanography, 31: 478-490. DOI: 10.4319/lo.1986. 31.3.0478

LAMPERT, W., E. MCCAULEY \& B. F. MANLY. 2003. Trade-offs in the vertical distribution of zooplankton: ideal free distribution with costs? Proceedings of the Royal Society of London. Series B: Biological Sciences, 270: 765-773. DOI: 10.1098/rspb.2002.2291 
LAWRENCE, S. G., D. F. MALLEY, W. Y. FINDLAY, M. A. MACLVER \& I. L. DELBAERE. 1987. Method for estimating dry weight of freshwater planktonic rustaceans from measures of length and shape. Canadian Journal of Fisheries and Aquatic Sciences, 44: 264-274. DOI: 10.1139/f87-301

LEACH, T. H., B. E. BEISNER, C. C. CAREY, P. PERNICA, K. C. ROSE, Y. HUOT, J. A. BRENTRUP, I. DOMAIZON, H. P. GROSSART, B. W. IBELINGS, S. JACQUET, P. T. KELLY, J. A. RUSAK, J. D. STOCKWELL, D. STRAILE \& P. VERBURG. 2018. Patterns and drivers of deep chlorophyll maxima structure in 100 lakes: The relative importance of light and thermal stratification. Limnology and Oceanography, 63: 628-646. DOI: 10.1002/lno.10656

LETELIER, R. M., D. M. KARL, M. R. ABBOTT \& R. R. BIDIGARE. 2004. Light driven seasonal patterns of chlorophyll and nitrate in the lower euphotic zone of the North Pacific Subtropical Gyre. Limnology and Oceanography, 49: 508-519. DOI: 10.4319/ 10.2004.49.2.0508

LOFTON, M. E., T. H. LEACH, B. E. BEISNER \& C. C. CAREY. 2020. Relative importance of top-down vs. bottom-up control of lake phytoplankton vertical distributions varies among fluorescence-based spectral groups. Limnology and Oceanography, n/a. DOI: 10. 1002/lno.11465

MAISS, M., J. ILMBERGER \& K. O. MÜNNICH. 1994. Vertical mixing in Überlingersee (Lake Constance) traced by SF6 and heat. Aquatic Sciences, 56: 329-347. DOI: 10.1007/BF00877180

MASZCZYK, P. \& W. A. WURTSBAUGH. 2017. Brine shrimp grazing and fecal production increase sedimentation to the deep brine layer (monimolimnion) of Great Salt Lake, Utah. Hydrobiologia, 802: 7-22. DOI: 10. 1007/s10750-017-3235-y

MATISOFF, G. 1996. Effects of bioturbation on solute and particle transport in sediments. In: ALLEN, H. E. (ed.) Metal Contaminated Aquatic Sediments. Boca Raton: CRC Press.

MATTHEWS, B. \& A. MAZUMDER. 2005. Temporal variation in body composition $(\mathrm{C}$ :
N) helps explain seasonal patterns of zooplankton $\delta^{13 C}$. Freshwater Biology, 50: 502-515. DOI: $10.1111 / \mathrm{j} .1365-2427.2005 .01336 . x$

MIRACLE, M. R. \& E. VICENTE. 1983. Vertical distribution and rotifer concentrations in the chemocline of meromictic lakes. Hydrobiologia, 104: 259-267. DOI: 10.1007/ BF00045976

MIRACLE, M. R., E. VICENTE. \& C. PEDRÓS-ALIÓ. 1992. Biological studies of Spanish meromictic and stratified karstic lakes. Limnetica, 8: 59-77.

MIRACLE, M. R. \& X. ARMENGOL. 1995. Population dynamics of oxyclinal species in lake Arcas-2 (Spain). Hydrobiologia, 313/314: 291-301. DOI: 10.1007/BF00025961

MIRACLE, M. R., A. CAMACHO, R. JULIÁ \& E. VICENTE. 2000. Sinking processes and their effect on the sedimentary record in the meromictic Lake La Cruz (Spain). Verhandlungen des Internationalen Verein Limnologie, 27: 1209-1213. DOI: 10.1080/03680770. 1998.11901428

MORATA, S. M., A. CAMACHO, M. R. MIRACLE \& E. VICENTE. 2003. Asociaciones fitoplanctónicas y su periodicidad en un lago marcadamente estratificado. Limnetica, 22: 35-52.

OOMS-WILMS, A. L. 1997. Are bacteria an important food source for rotifers in eutrophic lakes? Journal of Plankton Research, 19: 1125-1141. DOI: 10.1093/plankt/19.8.1125

PHILLIPS, D. L. 2012. Converting isotope values to diet composition: the use of mixing models. Journal of Mammalogy, 93: 342-352. DOI: 10.1644/11-mamm-s-158.1

PICAZO, A., C. ROCHERA, E. VICENTE, M. R. MIRACLE \& A. CAMACHO. 2013. Spectrophotometric methods for the determination of photosynthetic pigments in stratified lakes: a critical analysis based on comparisons with HPLC determinations in a model lake. Limnetica, 32: 139-158.

PILATI, A. \& W. A. WURTSBAUGH. 2003. Importance of zooplankton for the persistence of a deep chlorophyll layer: A limnocorral experiment. Limnology and Oceanography, 48: 249-260. DOI: 10.4319/lo.2003.48.1.0249 QUAY, P. D., W. S. BROEKER, R. H. HESS- 
LEIN \& D. W. SCHINDLER. 1980. Vertical diffusion rates determined by tritium tracer experiments in the thermocline and hypolimnion of two lakes. Limnology and Oceanography, 25: 201-218. DOI: 10.4319/ 10.1980.25.2.0201

RICHARDSON, T. L. \& J. J. CULLEN. 1995. Changes in buoyancy and chemical composition during growth of a coastal marine diatom: ecological and biogeochemical consequences. Marine Ecology Progress Series, 128: 77-90. DOI: $10.3354 / \operatorname{meps} 128077$

RODRIGO, M. A., E. VICENTE \& M. R. MIRACLE. 1993. Short-term calcite precipitation in the karstic meromictic lake La Cruz (Cuenca, Spain). Vereinigung fur Theoretische und Angewandte Limnologie, 25: 711-719. DOI: 10.1080/03680770.1992.11900231

RUTTNER-KOLISKO, A. 1997. Suggestions for biomass calculation of planktonic rotifers. Archiv fur Hydrobiolia, 8: 71-76.

SANFUL, P. O., M. K. OTU, H. KLING \& R. E. HECKY. 2017. Occurrence and seasonal dynamics of metalimnetic deep chlorophyll maximum (DCM) in a stratified meromictic tropical lake and its implications for zooplankton community distribution. International Review of Hydrobiology, 102: 135-150. DOI: 10.1002/iroh.201701899

SCOFIELD, A. E., J. M. WATKINS, B. C. WEIDEL, F. J. LUCKEY \& L. G. RUDSTAM. 2017. The deep chlorophyll layer in Lake Ontario: extent, mechanisms of formation, and abiotic predictors. Journal of Great Lakes Research, 43: 782-794. DOI: 10.1016/j. jglr.2017.04.003

SCOFIELD, A. E., J. M. WATKINS, E. OSANTOWSKI \& L. G. RUDSTAM. 2020. Deep chlorophyll maxima across a trophic state gradient: A case study in the Laurentian Great Lakes. Limnology and Oceanography, n/a. DOI: 10.1002/lno.11464

SENDRA, M. D., M. R. MIRACLE, E. VICENTE, A. PICAZO \& A. CAMACHO. 2019. Temporal succession, spatial dynamics and diversity of phytoplankton in the meromictic Laguna de la Cruz: the role of stratification patterns. Limnetica, 38: 1-20. DOI: 10.23818/limn.38.09
SILSBE, G. M. \& S. Y. MALKIN. 2016. Where light and nutrients collide: The global distribution and activity of subsurface chlorophyll maximum layers. In: P., G. \& T., K. (eds.) Aquatic Microbial Ecology and Biogeochemistry: A Dual Perspective. Cham: Springer.

SIMONCELLI, S., S. J. THACKERAY \& D. J. WAIN. 2017. Can small zooplankton mix lakes? Limnology and Oceanography Letters, 2: 167-176. DOI: 10.1002/lol2.10047

TURNER, J. T. 2015. Zooplankton fecal pellets, marine snow, phytodetritus and the ocean's biological pump. Progress in Oceanography, 130: 205-248. DOI: 10.1016/j.pocean.2014. 08.005

TWISS, M. R., C. ULRICH, A. ZASTEPA \& F. R. PICK. 2012. On phytoplankton growth and loss rates to microzooplankton in the epilimnion and metalimnion of Lake Ontario in mid-summer. Journal of Great Lakes Research, 38: 146-153. DOI: 10.1016/j.jglr. 2012.05.002

VADEBONCOEUR, Y. \& M. E. POWER. 2017. Attached algae: The cryptic base of inverted trophic pyramids in freshwaters. Annual Review of Ecology, Evolution, and Systematics, 48: 255-279. DOI: 10.1146/annurevecolsys-121415-032340

WILKINSON, G. M., S. R. CARPENTER, J. J. COLE \& M. L. PACE. 2014. Use of deep autochthonous resources by zooplankton: Results of a metalimnetic addition of $13 \mathrm{C}$ to a small lake. Limnology and Oceanography, 59: 986-996. DOI: 10.4319/1o.2014.59.3.0986

WILLIAMSON, C. E., R. W. SANDERS, R. E. MOELLER \& P. L. STUTZMAN. 1996. Utilization of subsurface food resources for zooplankton reproduction: Implications for diel vertical migration theory. Limnology and Oceanography, 41: 224-233. DOI: 10.4319/ 1o.1996.41.2.0224

WINDER, M., M. BOERSMA \& P. SPAAK. 2003. On the cost of vertical migration: are feeding conditions really worse at greater depths? Freshwater Biology, 48: 383-393. DOI: $10.1046 / j .1365-2427.2003 .00995 . x$

WURTSBAUGH, W. A. 2007. Nutrient cycling and transport by fish and terrestrial insect nutrient subsidies to lakes. Limnology and 
Oceanography, 52: 2715-2718. DOI: 10 . 4319/1o.2007.52.6.2715

WURTSBAUGH, W. A. \& D. NEVERMAN.
1988. Post-feeding thermotaxis and daily vertical migration in a larval fish. Nature, 333 : 846-848. DOI: $10.1038 / 333846 a 0$ 